\title{
ПРОГРАМА ВДОСКОНАЛЕННЯ ВИКЛАДАННЯ У ВИЩІЙ ОСВІТІ: ПЕРШИЙ ЦИКЛ
}

https://doi.org/10.37472/2707-305X-2020-2-1-4-3

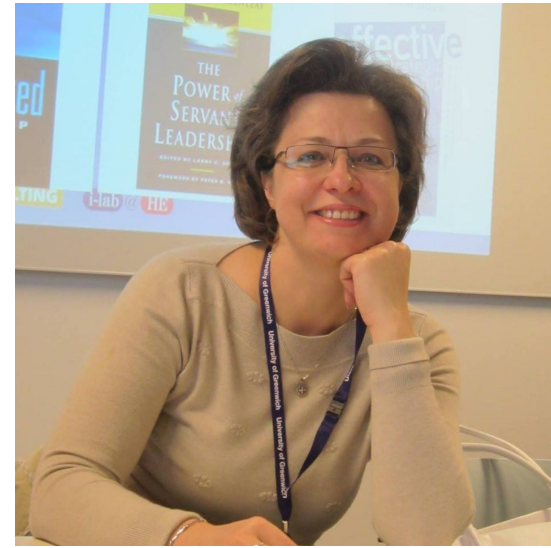

КАЛАШНІКОВА

Світлана Андріївна

доктор педагогічних наук, профресор, член-кореспондент НАПН України, директор Інституту вищої освіти Національної академії педагогічних наук України, м. Київ, Україна

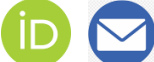

Анотація. Представлено роботу вчених Інституту вищої освіти НАПН України з реалізації Програми вдосконалення викладання, що проводиться у партнерстві з Британською Радою в Україні, за участю британської агениії Advance HE та за підтримки Міністерства освіти і науки України і Національного агентства забезпечення якості вищої освіти. Мета Програми - підвищення якості вищої освіти України шляхом розвитку інституційної спроможності університетів України щодо вдосконалення викладання $і$ навчання. у межах виконання Програми передбачено навчання викладачів університетів; профессійний розвиток представників керівного складу закладів вищої освіти; розроблення i реалізацію інституиійних проєктів університетів; розроблення Національної електронної платформи «Вища освіта України: кращі практики»; підготовку та видання посібника для викладачів університетів та онлайн-курсу для молодих викладачів томо. Навчання викладачів університетів розпочалося у травні 2020 р. із серії вебінарів, на яких обговорювалися питання про використання онлайн-технологій у навчанні; вплив емоцій на ефективність навчання; очінювання результатів навчання студентів та особливості зворотного зв'язку; забезпечення інтерактивності під час викладання; способи залучення студентів до активної взаємодії тощо.

Ключові слова: інституційна спроможність; якість вищої освіти; вдосконалення викладання; професійний розвиток.

Програма вдосконалення викладання у вищій освіті (далі Програма) реалізується Інститутом вищої освіти Національної академії педагогічних наук України у партнерстві з Британською Радою в Україні, з участю британської агенції Advance HE та за підтримки Міністерства освіти і науки України та Національного агентства забезпечення якості вищої освіти.

Mета Програми - підвищення якості вищої освіти України шляхом розвитку інституційної спроможності університетів України щодо вдосконалення викладання і навчання.

Протягом трьох років (2019-2021рр.) до участі у Програмі планується залучити університетські команди 30 університетів України (у складі трьох викладачів і одного представника управлінської команди університету).

Вимоги до учасників команди - викладачів:

- досвід викладання у вищій освіті (не менше 5 років);

- володіння англійською мовою (рівень В2 і вище);

- активне використання у викладацькій діяльності інноваційних методів і технологій;

- зобов'язання відвідувати всі модулі програми і брати активну участь у онлайн взаємодії;

- готовність використовувати нові знання і вміння у власній викладацькій діяльності;

- готовність ділитися знаннями і досвідом з іншими учасниками Програми та колегами-викладачами шляхом проведення тренінгів 
у власних закладах вищої освіти та в інших університетах України.

Вимоги до учасників команди - управлінців:

- професійний розвиток викладачів має належати до сфери посадових обов'язків;

- досвід викладання у вищій освіті (не менше 5 років);

- досвід управління освітньою діяльністю (не менше 2 років);

- зобов'язання відвідувати відповідні модулі Програми;

- зобов'язання сформувати команду в університеті, яка буде займатися розвитком і реалізацією інституційного проєкту, забезпечити управління інституційним проєктом, керівництво командою та своєчасне звітування про роботу;

- готовність до активного обміну кращими практиками з реалізації інституційних проєктів щодо вдосконалення викладання і навчання.

Відбір команд здійснювався на конкурсній основі за такими критеріями: якість поданої проєктної заявки; план заходів із розповсюдження результатів проєкту; забезпечення сталості результатів проєкту; якісний склад команди.

3 метою консультування університетських команд щодо питань підготовки заявки для участі у конкурсі Британська Рада в Україні спільно 3 Інститутом вищої освіти НАПН України проводила інформаційні зустрічі й відеоконференції.

За результатами конкурсного відбору, що відбувся на початку 2020 р., до участі у першому циклі Програми увійшли команди 10 університетів, серед яких:

- Запорізький національний університет;

- Київський національний університет імені Тараса Шевченка;

- Львівський національний університет імені Івана Франка;

- Мелітопольський державний педагогічний університет імені Богдана Хмельницького;

- Національний університет «Острозька академія»;

- Ніжинський державний університет імені Миколи Гоголя;

- Національний технічний університет «Дніпровська політехніка»;

- Сумський державний університет;

- Тернопільський національний педагогічний університет імені Володимира Гнатюка;

- Український державний університет залізничного транспорту.

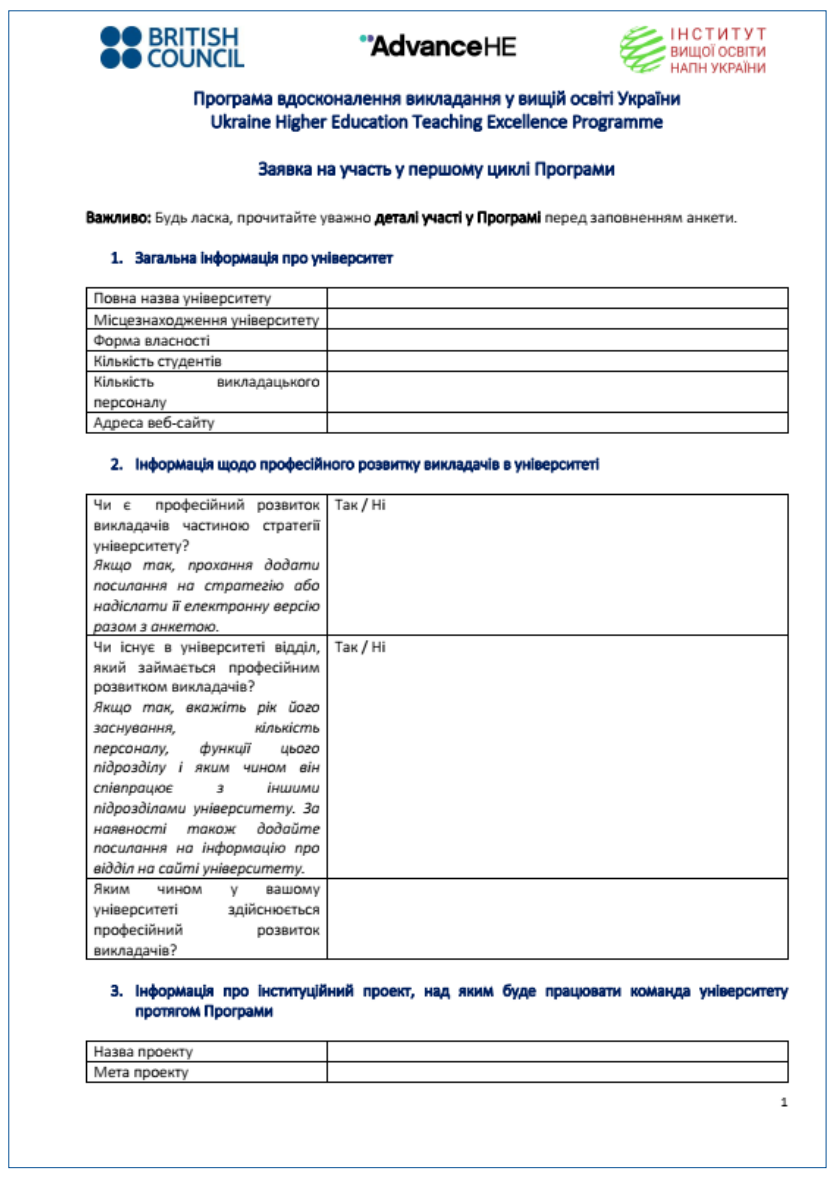

у межах реалізації Програми передбачено здійснення низки ініціатив, спрямованих на підсилення інституційної спроможності закладів вищої освіти України щодо вдосконалення викладання, зокрема:

- навчання викладачів університетів;

- професійний розвиток представників керівного складу закладів вищої освіти;

- розроблення і реалізація інституційних проєктів університетів;

- розроблення Національної електронної платформи «Вища освіта України: кращі практики»;

- підготовка та видання посібника для викладачів університетів та онлайн-курсу для молодих викладачів та ін.

Навчання викладачів університетів розпочалося у травні 2020 р. із серії вебінарів. Серед запропонованих для обговорення тем:

- використання онлайн-технологій у навчанні;

- вплив емоцій на ефективність навчання;

- оцінювання результатів навчання студентів та особливості зворотного зв'язку;

- як забезпечити інтерактивність під час викладання;

- способи залучення студентів до активної взаємодії тощо. 
Під час навчання в онлайн-режимі викладачі університетів використовують широкий спектр IKT-засобів, мають доступ до спеціальної електронної платформи, великої кількості корисних джерел і навчальних матеріалів, активно спілкуються між собою. За результатами реалізації цього онлайн-етапу викладачі університетів учасники Програми проводять для колег мінізаняття, що супроводжуються детальним аналізом і зворотним зв' язком.

\section{СПИСОК ВИКОРИСТАНИХ ДЖЕРЕЛ}

Інститут вищої освіти НАПН України. (2019, 9 грудня). Проєкт «Програма вдосконалення викладання у вищій освіті» (2019-2021 роки). https:// ihed.org.ua/internationalization/tehe_ukraine/
Advance HE. (n.d.). Home. https://www.advance-he.ac.uk/ British Council Ukraine. (n.d.). Програма вдосконалення викладання у вищій освіті України. http:// www.britishcouncil.org.ua/programmes/education/ higher-education-employability/teaching-excellenceprogramme

British Council Ukraine. (2019, 4 грудня). Українобританський форум "Досконалість викладання і навчання у вищій освіmi» [Video]. YouTube. https:// youtu.be/dgdVsbVT7Ks

Dexter, B. (2019). Ukraine Higher Education Teaching Excellence Programme. Initial analysis. https:// bit.ly/3OHHYJY

Killingley, P. (2019). Ukraine Higher Education Leadership Development Programme: Impact Report. Британська Рада в Україні. https://ihed.org.ua/wp-content/ uploads/2019/11/LDP_Impact-Report_BC_eng.pdf

\section{UKRAINE HIGHER EDUCATION TEACHING EXCELLENCE PROGRAMME: THE FIRST CYCLE}

\section{Svitlana Kalashnikova}

DSc in Education, Professor, Corresponding Member of NAES of Ukraine, Director, Institute of Higher Education of the National Academy of Educational Sciences of Ukraine, Kyiv, Ukraine

Abstract. The Institute of Higher Education of NAES of Ukraine researchers' work in the implementation of Ukraine Higher Education Teaching Excellence Programme is presented. The Programme is conducted in partnership with the British Council in Ukraine, Advance HE (UK) and with the support of the Ministry of Higher Education and Science of Ukraine and National Agency for in Higher Education Quality Assurance. Aim of the Programme is to foster quality of higher education of Ukraine through developing institutional capacity in teaching and learning excellence. The Programme seeks to realise the academic staff training; to develop and realise institutional projects of universities; to launch a national online platform "Higher Education in Ukraine: the Best Practices"; to publish a manual for academic staff and prepare an online course for young university teachers, etc. The training of university teachers began in May, 2020 with webinars on using the online technologies in teaching; the influence of emotions on leaning efficiency; the assessment of students' learning outcomes and feedback features; providing interactivity in teaching; the ways to involve students in active interaction, etc.

Keywords: institutional capacity; higher education quality; teaching excellence; professional development.

Дата публікації: 16 червня 2020 р. 